\title{
(2) OPEN ACCESS \\ Sustained response to imatinib in patient with extraskeletal myxoid chondrosarcoma and novel KIT mutation
}

\author{
Brooke Jennings $\odot,{ }^{1,2}$ John Rieth, ${ }^{2,3}$ Travis Snyders, $^{3}$ Mohammed Milhem ${ }^{3}$
}

'Department of Molecular Physiology and Biophysics, The University of lowa Roy J and Lucille A Carver College of Medicine, lowa City, lowa, USA ${ }^{2}$ Department of Internal Medicine, The University of lowa Hospitals and Clinics, lowa City, lowa, USA

${ }^{3}$ Holden Comprehensive Cancer Center, The University of lowa Hospitals and Clinics, lowa City, lowa, USA

\section{Correspondence to} Brooke Jennings;

brooke-jennings@uiowa.edu

Accepted 15 August 2021
Check for updates

(c) BMJ Publishing Group Limited 2021. Re-use permitted under CC BY-NC. No commercial re-use. See rights and permissions. Published by BMJ.

To cite: Jennings B, Rieth J, Snyders T, et al. BMJ Case Rep 2021;14:e242039. doi:10.1136/bcr-2021242039

\section{SUMMARY}

A 55-year-old woman presented with a 3-month history of right groin swelling, discomfort and impaired mobility. On examination, a palpable mass was noted both to the right of midline in the lower abdomen and in the right groin. MRI of the pelvis showed two masses involving the anterior abdominal wall and right groin, as well as lymph node involvement. CT imaging revealed multiple bilateral pulmonary metastases. Pathology demonstrated a myxohayline stroma morphology. Tumour was also notable for $N R 4 A 3$ gene region rearrangement and mutation in KIT exon 11 at position c. 1669 T>G. Based on these findings, she was diagnosed with extraskeletal myxoid chondrosarcoma (EMC). The patient has been on imatinib, a tyrosine kinase inhibitor with activity against KIT, for 3 years with stable disease. Metastatic EMC is generally treated with surgical resection and perioperative radiation therapy with adjuvant chemotherapy and is associated with poor prognosis.

\section{BACKGROUND}

Extraskeletal myxoid chondrosarcoma (EMC) is a rare soft-tissue sarcoma (STS) subtype that contains myxoid matrix located in soft tissues, typically occurring near the proximal end of long bones. ${ }^{1}$ The cellular lineage of EMC continues to be an issue of debate. Despite its name, the tumour is not considered a subtype of chondrosarcoma, as hyaline cartilaginous neoplastic tissue is not always present. $^{2}$ EMC tumours can present variably on imaging, with a majority demonstrating a lowdensity mass with calcification on CT with mild or no enhancement. ${ }^{2}$ These tumours usually present in patients over 40 years of age and are more common in males than females, with one study identifying a distribution of $64 \%$ males, and $84 \%$ of patients diagnosed after the age of $39 .^{3}$ The lower extremity is the most common primary tumour site, with one study identifying $57 \%$ of cases with a lower extremity primary. ${ }^{3}$ Classically, EMC is characterised by translocations with the NRA3 gene with EWSR1 or TAF15. ${ }^{4}$ Rare cases of NRA3 translocation with TCF12 and TFG, and RET overexpression have also been reported. ${ }^{5-7}$ One rare case reported an in-frame deletion (c.1735_1737del) in exon 11 of $\mathrm{KIT}^{8}{ }^{8}$

For patients with localised and resectable metastatic STS, the mainstay of treatment remains surgical resection with perioperative radiation therapy in addition to adjuvant chemotherapy. ${ }^{9} 10$ EMC is a unique sarcoma with a propensity for local recurrence and metastasis. Localised EMC usually has a relatively indolent course, with a 15 -year overall survival of 58\%; however, prognosis is much worse in the setting of metastatic EMC, with a reported median survival of $<18$ months from the onset of metastatic disease. Cytotoxic chemotherapy is relatively ineffective in the metastatic setting, with no significant radiologic or clinical responses noted in a number of trials, with median time to disease progression of 5.2 months. ${ }^{11}$ Despite poor responses to cytotoxic chemotherapy, patients have had better response to sunitinib, a vascular endothelial growth factor receptor (VEGF) tyrosine kinase inhibitor. ${ }^{12}$

Here, we report a case of extraskeletal myxoid chondrosarcoma with novel somatic mutation in KIT exon 11 at position c. $1669 \mathrm{~T}>\mathrm{G}$ with remarkable and sustained response to imatinib.

\section{CASE PRESENTATION}

A 55-year-old woman presented with a 3-month history of right groin swelling, discomfort and impaired mobility. On examination, a palpable mass was noted both to the right of midline in the lower abdomen and in the right groin. Her family history is negative for malignancy of any kind.

\section{INVESTIGATIONS}

MRI of the pelvis identified a $6.8 \times 4.3 \times 2 \mathrm{~cm}$ mass of the midline anterior abdominal wall, a $2.3 \times 2.2 \mathrm{~cm}$ mass of the right groin, and two right pelvic lymph nodes. CT imaging revealed multiple bilateral pulmonary metastases.

A partial excisional biopsy of the groin mass was performed, and pathology demonstrated primarily epithelioid cells in nests, cords and sheets in a myxohyaline stroma, as shown in figure 1 . An array of immunohistochemical stains was performed on the tumour, including PD-L1, pan-cytokeratin AE1/AE3, OSCAR, CK7, CK20, TTF- 1 and S100 protein, which were negative. In situ hybridisation was notable for NR4A3 gene region rearrangement. Together, these findings were consistent with highgrade extraskeletal myxoid chondrosarcoma. Interestingly, the cancer mutation analysis was notable for the missense variant c.1669 T>G in KIT exon 11 , never before seen in EMC. Germline mutation analysis was conducted on a blood sample, and the novel KIT mutation was not present, indicating a somatic mutation. One other case reported in the literature demonstrated a deletion in-frame 


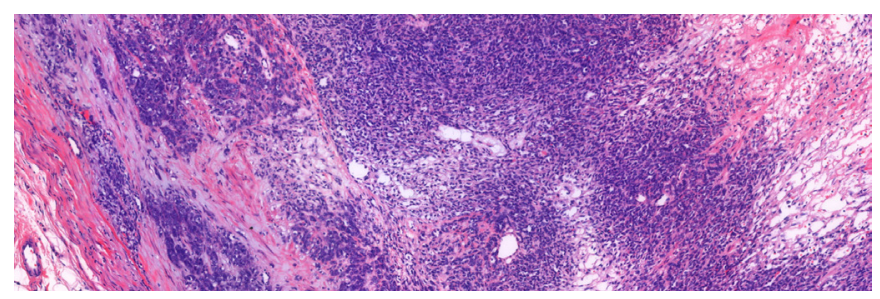

Figure 1 Histopathology of the tumour showing epithelioid cells in nests, cords and sheets in a myxohyaline stroma.

deletion (c.1735_1737del) in KIT in exon 11 in a patient with EMC.

\section{TREATMENT}

The patient was initially treated with zoledronic acid prior to the results of her mutation analysis. After discovery of the novel KIT mutation c.1669 T>G, she was subsequently treated with imatinib, a tyrosine kinase inhibitor with activity against KIT.

\section{OUTCOME AND FOLLOW-UP}

Her disease has been stable for 3 years on continued therapy with minimal gastrointestinal side effects.

\section{DISCUSSION}

STS account for $1 \%$ of newly diagnosed cancers in adults, with EMC being a rare subtype within this group. Doxorubicin with or without ifosfamide has remained the first-line therapy treatment of metastatic STS. ${ }^{13}$ Due to the rarity, limited research is available specifically focused on EMC, although previous studies suggest that cytotoxic chemotherapy, including doxorubicin, is ineffective for treatment. ${ }^{11}$

This patient demonstrated the missense mutation in KIT exon 11 at position c. $1669 \mathrm{~T}>\mathrm{G}$, never before reported in EMC. KIT, a proto-oncogene, is known to play an important role in cell proliferation, differentiation, migration and apoptosis. The $1669 \mathrm{~T}>\mathrm{G}$ mutation is predicted to cause a tryptophan to glycine substitution at the position 557, resulting in a gain-offunction mutationin KIT. ${ }^{14}$ Gain-of-function mutations in KIT are primarily associated with gastrointestinal stromal tumours (GIST) but have also been found in melanoma and acute myelogenous leukaemia. ${ }^{15-17}$

Imatinib is tyrosine kinase competitive inhibitor with activity against KIT, PDGFRA and other tyrosine kinases. Imatinib has shown efficacy in GIST and chronic myeloid leukaemia. ${ }^{18} 19$ The patient presented here has been on imatinib for 3 years and continues to have stable disease.

\section{Learning points}

Extraskeletal myxoid chondrosarcomas are extremely rare, with diagnosis relying on pathological, immunohistochemical and molecular evaluation.

- The c.1669 T>G mutation in KIT exon 11 has never before reported in extraskeletal myxoid chondrosarcomas.

- Imatinib provided a strong and sustained treatment response, indicating a possible treatment option for any cancers containing a KIT mutation regardless of known association.
Acknowledgements We would like to thank the patient for their willingness to share the details we presented here. We would also like to thank Dr. Tanas Munir, University of lowa Hospitals \& Clinics Department of Pathology, for providing the H\&E stain imaging.

Contributors Supervised by MM, patient care provided by MM. Care was also provided by TS. Report was written by BJ, JR and TS.

Funding The authors have not declared a specific grant for this research from any funding agency in the public, commercial or not-for-profit sectors.

Competing interests None declared.

\section{Patient consent for publication Obtained.}

Provenance and peer review Not commissioned; externally peer reviewed.

Open access This is an open access article distributed in accordance with the Creative Commons Attribution Non Commercial (CC BY-NC 4.0) license, which permits others to distribute, remix, adapt, build upon this work non-commercially, and license their derivative works on different terms, provided the original work is properly cited and the use is non-commercial. See: http://creativecommons.org/ licenses/by-nc/4.0/

\section{ORCID iD}

Brooke Jennings http://orcid.org/0000-0003-4751-7288

\section{REFERENCES}

1 Zaki M, Laszewski P, Robinette N, et al. Unresectable extraskeletal myxoid chondrosarcoma of the neck: early tumor response to chemoradiotherapy. Cureus 2015;7:e432.

2 Zhang L, Wang R, Xu R, et al. Extraskeletal myxoid chondrosarcoma: a comparative study of imaging and pathology. Biomed Res Int 2018;2018:1-9.

3 Wagner MJ, Chau B, Loggers ET, et al. Long-Term outcomes for extraskeletal myxoid chondrosarcoma: a SEER database analysis. Cancer Epidemiol Biomarkers Prev 2020:29:2351-7.

4 Flucke U, Tops BBJ, Verdijk MAJ, et al. Nr4A3 rearrangement reliably distinguishes between the clinicopathologically overlapping entities myoepithelial carcinoma of soft tissue and cellular extraskeletal myxoid chondrosarcoma. Virchows Arch 2012;460:621-8

5 Benini S, Cocchi S, Gamberi G, et al. Diagnostic utility of molecular investigation in extraskeletal myxoid chondrosarcoma. J Mol Diagn 2014;16:314-23.

6 Davis EJ, Wu Y-M, Robinson D, et al. Next generation sequencing of extraskeletal myxoid chondrosarcoma. Oncotarget 2017;8:21770-7.

7 Hisaoka M, Ishida T, Imamura T, et al. Tfg is a novel fusion partner of NOR1 in extraskeletal myxoid chondrosarcoma. Genes Chromosomes Cancer 2004;40:325-8.

8 Urbini $M$, Indio $\mathrm{V}$, Astolfi $\mathrm{A}$, et al. Identification of an actionable mutation of kit in a case of extraskeletal myxoid chondrosarcoma. Int J Mol Sci 2018;19:1855.

9 O'Sullivan B, Davis AM, Turcotte R, et al. Preoperative versus postoperative radiotherapy in soft-tissue sarcoma of the limbs: a randomised trial. Lancet 2002;359:2235-41.

10 Rosenberg SA, Tepper J, Glatstein E, et al. The treatment of soft-tissue sarcomas of the extremities: prospective randomized evaluations of (1) limb-sparing surgery plus radiation therapy compared with amputation and (2) the role of adjuvant chemotherapy. Ann Surg 1982;196:305-15.

11 Drilon AD, Popat S, Bhuchar G, et al. Extraskeletal myxoid chondrosarcoma: a retrospective review from 2 referral centers emphasizing long-term outcomes with surgery and chemotherapy. Cancer 2008;113:3364-71.

12 Stacchiotti S, Pantaleo MA, Astolfi A, et al. Activity of sunitinib in extraskeletal myxoid chondrosarcoma. Eur J Cancer 2014;50:1657-64.

13 Borden EC, Amato DA, Rosenbaum C, et al. Randomized comparison of three adriamycin regimens for metastatic soft tissue sarcomas. J Clin Oncol 1987;5:840-50

14 Nakahara M, Isozaki K, Hirota S, et al. A novel gain-of-function mutation of c-kit gene in gastrointestinal stromal tumors. Gastroenterology 1998;115:1090-5.

15 Miettinen M, Lasota J. Gastrointestinal stromal tumors: pathology and prognosis at different sites. Semin Diagn Pathol 2006;23:70-83.

16 Gong HZ, Zheng HY, Li J. The clinical significance of kit mutations in melanoma: a meta-analysis. Melanoma Res 2018;28:259-70.

17 Ayatollahi $\mathrm{H}$, Shajiei A, Sadeghian $\mathrm{MH}$, et al. Prognostic importance of c-kit mutations in core binding factor acute myeloid leukemia: a systematic review. Hematol Oncol Stem Cell Ther 2017;10:1-7.

18 Blanke CD, Demetri GD, von Mehren $M$, et al. Long-Term results from a randomized phase II trial of standard- versus higher-dose imatinib mesylate for patients with unresectable or metastatic gastrointestinal stromal tumors expressing kit. J Clin Oncol 2008;26:620-5.

19 Hochhaus A, Larson RA, Guilhot F, et al. Long-Term outcomes of imatinib treatment for chronic myeloid leukemia. N Engl J Med 2017;376:917-27. 
Copyright 2021 BMJ Publishing Group. All rights reserved. For permission to reuse any of this content visit https://www.bmj.com/company/products-services/rights-and-licensing/permissions/

BMJ Case Report Fellows may re-use this article for personal use and teaching without any further permission.

Become a Fellow of BMJ Case Reports today and you can:

- Submit as many cases as you like

Enjoy fast sympathetic peer review and rapid publication of accepted articles

Access all the published articles

Re-use any of the published material for personal use and teaching without further permission

Customer Service

If you have any further queries about your subscription, please contact our customer services team on +44 (0) 2071111105 or via email at support@bmj.com.

Visit casereports.bmj.com for more articles like this and to become a Fellow 